\title{
Tropical Dendroclimatology in the Ecuadorian Amazon with Cedrela odorata
}

\author{
Sheila Serrano ${ }^{1}$, Lisseth Carlosama, Madison Herrera \\ ${ }^{1}$ Environmental Modeling Research Center (CIMA)/ Environmental Science Research group (GRICAM)/ Salesian \\ Polytechnic University \\ Av. Rumichaca y Morán Valverde s/n, Quito, Ecuador \\ sserranov@ups.edu.ec
}

\section{Extended Abstract}

Dendroclimatology studies the relationship between the growth of tree rings and climatic variables, serving as climate proxy from past times to the present day, especially in places where instrumental records are sparse [1]. The Ecuadorian Amazon is characterized by its constant and uniform precipitation, with no clear seasonal pattern for the onset of a dormant period and consequent ring formation in tropical trees. However, field exploration campaigns and literature review, confirms that Cedrela odorata is a forest species that sheds its leaves annually at the end of the season of minimal amount of precipitation (July - September), triggering the ring formation.

The study was carried out in the karst area of the Amazon region of Ecuador [2] between the Anzu and Pastaza rivers, in the humid forest located within the bio-corridor between the National Parks "Sangay" and "Llanganates", in a heterogeneous forest with under domain of species and a great diversity (this, as a result of the twenty-one different species of trees being found on 0.1 hectares during the exploration). The high precipitation of Atlantic origin condenses at the foothills of the eastern flank of the Andean mountain range. Temperature records in the area show minimum temperature fluctuations with high humidity [3], [4]. Therefore, for the study of the climatic patterns in the area, sixty-four trees were sampled with a haglöf 3-thread increment borers, obtaining a total of one hundred and twenty-eight tree cores (at least two samples of each one) and processed using classical dendrochronological methods [5]. Of the 21 tropical species found, only nine showed rings because their anatomical formation in many cases was very complex. Finally, only two were useful: Cederela odorata and Protium sp.

Tree ring widths (TRW) were measured in a LINTAB 6 station, crossdated and obtained a final chronology with a mean age of 60 years. The chronology was calibrated with climatic data from two meteorological stations of the National Institute of Meteorology and Hydrology (INAMHI) and Civil Aviation Directorate (DAC) using dendroclimatic (dplR) and (bootRes) packages in $\mathrm{R}$ 3.6.0 statistical program [6]-[8].

The results show that the growth of the species Cedrela odorata obeys the periods of more intense rainfall in the area (April - June and October - December) with a temperature drop that follows the reduction of rainfall in the months from June to September, confirming the bimodal behavior existing in the study site. Another species with dendroclimatological potential is Protium sp., due to it shows a good correlation with relative humidity or evaporation.

\section{References}

[1] H. C. Fritts, Tree Rings and Climate, vol. 15, no. 1. New York: ACADEMIC PRESS INC., 1976.

[2] S. Constantin, T. Toulkeridis, O. T. Moldovan, M. Villacís, and A. Addison, "Caves and karst of Ecuador - state-ofthe-art and research perspectives," Phys. Geogr., vol. 40, no. 1, pp. 28-51, 2018.

[3] L. Campozano, R. Célleri, K. Trachte, J. Bendix, and E. Samaniego, "Rainfall and Cloud Dynamics in the Andes: A Southern Ecuador Case Study," Adv. Meteorol., vol. 2016, pp. 1-15, 2016.

[4] L. Campozano et al., "Climatology and Teleconnections of Mesoscale Convective Systems in an Andean Basin in Southern Ecuador: The Case of the Paute Basin," Adv. Meteorol., vol. 2018, pp. 1-13, 2018.

[5] R. L. Phipps, "COLLECTING, PREPARING, CROSSDATING, AND MEASURING TREE AND INCREMENTE CORES," Water-Resources Investisations Rep. 85-4148, 1985.

[6] A. G. Bunn, "A dendrochronology program library in R (dplR),” Dendrochronologia, vol. 26, no. 2, pp. 115-124, 2008. 
[7] A. G. Bunn, "Statistical and visual crossdating in R using the dplR library," Dendrochronologia, vol. 28, no. 4, pp. 251-258, 2010.

[8] C. Zang and F. Biondi, "Dendroclimatic calibration in R: The bootRes package for response and correlation function analysis," Dendrochronologia, vol. 31, no. 1, pp. 68-74, 2013. 